\title{
To Do or To Listen? Student Active Learning vs. the Lecture
}

\author{
Pål Anders Opdal ${ }^{1}$ iD
}

Accepted: 19 July 2021 / Published online: 4 August 2021

(C) The Author(s) 2021

\begin{abstract}
This paper is a discussion of the concept 'student active forms of learning'. It aims not at conclusions, but at a perspicuous representation - a map for future navigation and understanding of the concept. From the perspective of philosophy of education, I characterize and discuss issues relating to student active learning in the paper. The context for my discussion is higher education. Further, I contrast student active learning to a form of learning that is allegedly passive, the lecture, which traditionally is the main form of learning in higher education. I proceed by assessing arguments in favor of the two forms by way of a philosophical analysis, a main component of which is transparent exposition. Positive conclusions are not the main concern, but rather to demonstrate possibilities. Still, two results of the discussions in the paper are noteworthy: (1) 'student active learning' is a weak construct, it being too general or even contradictory; (2) the lecture is not passive, and a student-centered education, consequently, should not be construed as a dismissal of lecturing.
\end{abstract}

Keywords Student active learning $\cdot$ The lecture $\cdot$ Passive learning $\cdot$ Constructivist teaching $\cdot$ Student centered education

\section{Introduction: Problem, Background, Purpose, Structure}

How do we best get our students to learn? I submit that making our students able to integrate and transfer knowledge are amongst the main purposes of higher education. If so, how are we to teach to maximize this in the student body? These questions are old, of course, but none the less hotly debated. Are we to lecture to our students, or should we rather have them engage in activities? Both in equal measure, or one predominantly? Are we, as teachers in higher education, experts and hence knowledgeable to the extent of being positioned to tell our students what is the case? Or should we rather look upon ourselves as facilitators of, or

Pål Anders Opdal

pal.a.opdal@uit.no

1 UiT-The Arctic University of Norway, Tromsø, Norway 
guides to, students' learning? And how should the answer to these questions be reflected in our teaching and the planning of it—in practical terms?

This paper is an extended discussion of these questions. Within the context of higher education, it seeks to answer, or at least to elucidate, the following: Which forms of learning are preferable, active or allegedly passive forms - and why? Is it possible to say something general in this regard? I write "allegedly" in the previous sentence because there is an argument to be made for learning necessarily being active, that it is not possible to learn passively. I consider this argument below, but as witnessed by my title, the alleged passive form of learning that I discuss in this paper is the lecture.

The background to the paper is the following two occurrences. (1) In The Beautiful Risk of Education Gert Biesta quotes Virginia Richardson with approval as she claims, "the elements of effective constructivist teaching is not known" (Richardson 2003, 1629; quoted from Biesta 2016, 45). This, I thought when I first read it, makes a lot of sense. Due to perceived institutional expectations, as well as hands-on teaching in courses that per selfproclamation are student-active, I was both obliged to, and had experienced how difficult it is, to conceive of activities for the students to do to realise diverse learning objectives. (For example, what kind of activities would realize the objective "is able to analyse"?) In subsequent writings, and following Knud Illeris (2012, 294f), I suggested characterizing student activity on a scale ranging from subject-based activity, over problem- and experience-based activity, to practically based activity (Opdal 2018, 256). But this, I found, is not so much finishing a meal as it is stirring the pot, so the issue stayed with me. In turn, this prompted me (2) to investigate into the research-literature pertaining to student active learning. It then soon became evident that (at least some of) the elements of constructivist teaching (at least according to some) are in fact well known. There exists an extensive body of empirical research addressing the question of what works in terms of teaching being constructive (e.g. Deslauriers et al. 2011; Freeman et al. 2014; Wieman 2014; 2019), and I consider some of this literature below. Further, there are fundamental, and enlightening, distinctions to be made between constructivism as a theory of learning and constructivism as a theory of teaching. As regards "student active forms of learning", this concept is problematic in and of itself, since it is perfectly possible to be active while passive and passive while active (more on this rather cryptic sentence below). There are, thus, fundamental problems connected to the very notion of active learning.

The purpose of this paper is three-fold. First, it is to identify, characterize and discuss the notion of student active forms of learning. As several writers have argued, "active learning" is ambiguous (e.g. Mayer 2004; 2009), and I consider this position below. At the same time, "active learning" plays a significant role in overarching European educational plans. The European Qualification framework, the overarching policy-frame for education in the European Educational Area and a fall-out from which is National Qualifications Frameworks currently in operation in 34 European countries, for example highlights the importance of learning as opposed to teaching and concurrently student activity and student-centeredness as opposed to "input-factors" (Ministry of Science, Technology and Innovation [MSTI] 2005; 38). In my native Norway, as a consequence, the act regulating quality-audits in higher education, demands forms of teaching, learning and assessment where didactical "arrangements are such that the student might take an active part in the learning-process" (Forskrift 2017, § 2-2, 5; translation mine). As precise terminology is a prerequisite for fruitful conceptualization and understanding, an identification and characterization of 'student 
active learning' might thus prove valuable. A second purpose of the paper is to analyse and discuss an allegedly passive form of learning, viz. the lecture. Since the opposite of active is passive, and since effective thinking often is thinking in contrasts, it seems worthwhile to position active learning by that which it is not, namely learning that is (allegedly) passive. Third, it is a purpose of the paper to investigate into the pros and cons of both active and passive learning. Despite active learning often being portrayed as a panacea, as a one-size fits all for higher education (e.g. Geven and Attard 2012; considered below), there seem good reason to believe that notions of differing educational traditions, subjects and levels, and of the maturity, motivation and interests of students, are necessary to say something worthwhile about which form of learning is preferable. Even if the existence of differing disciplines primarily is due to what we do (our object) and why we do it (to cure, to amend, to understand), centuries of scholas have also crystallized in disciplinary ways of doing things (our how). On this background, the existence of a universal best way seems unlikely.

I start below with reviewing parts of the literature pertaining to student active forms of learning (Sect. 2). The organizing principle of the review is arguments, meaning that the attempt is to characterize student active forms of learning by identifying and discussing some of the reasons that have been marshalled for and against it. I then (Sect. 3) discuss the lecture as an allegedly passive form of learning, and the same organizing principle applies, i.e. reasons pro et contra. These two sections afford me the opportunity to develop a table of arguments pertaining to active and (allegedly) passive learning. I present the table in Sect. 4 and discuss further one of the elements of it. In Sect. 5, I sum up and offer some words in conclusion. In this last section, I also answer some of the many questions posed on the opening page.

\section{Student Active Learning—Review by Way of Central Arguments}

The organizing principle of the following review is arguments pertaining to student active forms of learning. To get started, and to indicate what the arguments I review are arguments for, I follow Freeman et al., making use of their "consensus-definition" of active learning:

"Active learning" = def. "Active learning engages students in the learning process through activities and/or discussion in class, as opposed to passively listening to an expert". (2014, 8413f)

After having systematized parts of the literature pertaining to student active forms of learning, I have extrapolated the following arguments from the material:

- The empirical argument

- The activity-argument

- The argument from conceptual schemes

- The argument from purpose

- The argument from authority.

Note that extrapolating arguments from a material necessarily involves attribution (as does indeed giving arguments names). This means that the arguments are not necessarily stated 
in the material (the names are certainly not), but neither is the attribution far-fetched. In any case, I substantiate the attribution below by quoting closely from relevant material.

The empirical argument is the argument that students learn more and/or better under active conditions than under alternative didactical regimes (typically called "traditional" and including lecturing). The argument derives its name from what backs it, namely empirical research. Important in this connection is for example Freeman et al. (2014), who reports that "students in classes with traditional lecturing were 1.5 times more likely to fail than were students in classes with active learning" (8410) and that exam-scores "improved by about $6 \%$ in active learning conditions" (8410). Important is also Deslauriers et al. (2011) who in reporting from a study, claims that "more than twice the learning" (862) occurred under active conditions than under conditions that were non-active. Geven and Attard (2012) argue that "all types of active learning show a higher retention rate than traditional forms of learning" (167), and according to Gauci et al. (2009), the empirical argument is not restricted to cognitive dimensions. They report that students working under active conditions also become "'more engaged' $(83 \%)$, 'intellectually stimulated' $(85 \%)$, and 'motivated to think' $(89 \%)$ " (63), as compared to students working under traditional conditions.

The empirical argument appears strong. Why? Because it is difficult to argue against that which is the case. Still, some questions and comments are in order. First, it is clearly debatable what more/better learning means. Since there are important distinctions between documented learning (e.g. exam-score), actual learning (that which students actually learn-disregarding for example a bad exam-day) and intended learning (what the teacher wills that you learn), and since these need not overlap, fixating more/better learning is principally difficult. It would for example seem to depend upon when you measure it - and for what reason. Second, more/better learning, as measured by exam-score, lack sensitivity to learning being (what I call) organic, i.e. purposeful, i.e. constantly changing and developing over time and dependent upon perceived conditions of applicability. There is a story of an old fisherman, Frank, illustrative in this connection. During a storm he suddenly finds himself reciting psalm-verses that he had not thought about since his school days. But suddenly they appeared. Which learning is more and/or better is on this background not just a question of when you measure it, it is also a question of how the measurement is performed. Third, even if Carl Wieman have argued to the contrary $(2014 ; 2019)$, the empirical backing for active learning is ambiguous. Yureich and Kanner (2015), for example, report that even if student satisfaction increases under active conditions, performance on some exam questions decline. Consequently, that which is the case is not given after all, and, as a corollary, the empirical argument might be less substantiated than appear at first sight.

The activity-argument is the argument that human beings learn better when being active than when being passive. It is closely related to the empirical argument, but whilst the empirical argument derives backing from empirical investigations, the activity-argument derives backing from a feature of our human nature: that our ability to learn improves when we are active. John Biggs and Catherine Tang, influential researchers in the field of higher education, are important in this connection. They claim for example that "Being active while learning is better than being inactive. Activity is good in itself: it heightens physiological arousal in the brain which makes performance more efficient" $(2011,62)$. To paraphrase: because of how we are, our very nature, being physically active while learning is better, 
in the sense of more efficient, than being passive. This idea is also forcefully expressed by Ralph Tyler: "Learning takes place through the active behaviour of the student: it is what he does that he learns, not what the teacher says" $(1949,63)$.

The activity-argument, like the empirical argument, appears strong. If we are hard-wired to learn better when aroused than when not, and if we are aroused by physical activity, it seems the case is closed - and that we should just arrange didactical situations accordingly. Yet, there are problems also with the activity-argument. First, it is interesting to compare the claim that active learning makes performance more efficient with the claim that is debatable what more/better learning means, discussed above. The claim that activity makes performance more efficient must assume that documented learning is a valid expression of actual learning. But as argued above, this need not be the case, and thus efficiency has no precise measure. Second, as argued by Richard Mayer, the word "active" names two distinct concepts, "behaviourally active" on the one hand, and "cognitively active" on the other (2004; 2009). The activity-argument, as exemplified above, interprets "active" in the first sense, as behaviourally active. But this interpretation is incomplete. Why? Because it is perfectly possible to be cognitively active whilst behaviourally passive (cf. the cryptic sentence from the introduction). And so it is not true that (simpliciter:) human beings learn better when being active than when being passive. "Active", contrary, must be construed to include also "cognitively active", But if so, it seems the activity-argument is seriously jeopardized.

Imagine a university lecture. Sally the student is attentively listening to Tracy the teacher. Sally sits completely still and utters not a word. At the same time, myriad things are going on in her mind, for example: Questions (what does this mean?); understanding (this is lot like that); analyses (how does this compare to that?); critique (this cannot be right). This, of course, is activity.-But Sally is not active; she is after all sitting completely still? As the argument above shows, behavioural inactivity is compatible with cognitive activity. The case for the activity-argument is thus far from closed and, consequently, the argument does not imply any specific didactical organization.

Some might find this rendering of the activity-argument uncharitable. If so, assume a reading that is more favourable to the argument.-Certainly, the cognitive activity of the students is what is important. When we say "active" we mean of course not that behavioural activity is the end of the story, only that it is the beginning. Or, to put the matter differently, we argue that behavioural activity is a means to cognitive activity that is an end. Disregarding that the wording in the sources from which the activity-argument is extrapolated perhaps makes the charitable reading too charitable (refer back to the quotes from Biggs and Tang and Tyler above), there are, in my view, only small problems with this version of the activity-argument. It seems evident that behavioural activity might be a means to cognitive activity (an end), as on the charitable reading. But this is not always the case, and it is possible to be cognitively active to a high degree even if behaviourally completely passive.

The argument from conceptual schemes is the argument that since learning is a matter of integrating new knowledge/information with one's existing mental schemes, since this involves scheme-construction in the form of new- or reconstruction, and since this construction happens more readily/better under active than under passive conditions, didactical situations should be arranged accordingly. The scheme-idea is old, of course, dating back at least to Kant. In an educational context, however, it is primarily linked to the names Jean 
Piaget and Lev Vygotsky. A minimal characterization of Piaget and Vygotsky, in terms of the construction of mental schemes, might look like this: Learning is adjustment in mental schemes in the overall interest of equilibrium (e.g. Piaget 1967, 7ff); learning is making the interpersonal concepts and categories intrapersonal, respectively (e.g. Vygotsky 1978, 45ff). Since you achieve equilibrium and/or intrapersonal conceptual mastery more readily when you interact with your environment and/or your peers than when not, learning situations should be arranged for such interaction.

Mayer, discussed above, makes an interesting distinction between constructivist theories of learning and constructivist theories of teaching. He subscribes to a constructivist learning theory, as witnessed by the following quote: "learning is an active process in which learners are active sense makers who seek to build coherent and organized knowledge" (2004, 14). On the other hand, he is strongly critical of constructivist theories of teaching: "[I] $\mathrm{t}$ is inappropriate to assume that active cognitive learning requires teaching methods that promote hands-on behavioural activity" $(2009,184)$. He coins the expression the constructivist teaching fallacy in this connection: the idea that because learning is best conceived as constructivist, teaching is too. But this, according to Mayer, is a fallacy. Teaching is not constructivist - but should instead be by way of teacher-led worked examples, something for which lecturing is suitable. Clark et al. (2012), following up on Mayer's research, express this idea as follows, "for novices (comprising virtually all students), direct, explicit instruction is more effective and more efficient than partial guidance" (6). Again, even if learning is constructivist, teaching is not.

The argument from purpose is the argument that since a vital purpose in higher education is to teach students to transfer their learning - their knowledge and skills, but also, as a ramification, their beliefs and values, and since students learn to transfer more readily under active than under passive conditions, one is to arrange didactical situations accordingly. Smart and Csapo argues to this effect, when they claim that "the development of ... higher order thinking skills ... [happens when students are] engaged in activities" (2007, 452). Yureich and Kanner, similarly, argues that there is "ample evidence that these methods [i.e. active methods] promote critical thinking, higher order processing and greater retention of information than lecture only instruction" $(2015,147)$.

There is a vast literature relating to the transfer of learning (e.g. Barnett and Ceci 2002; Haskell 2001; Leberman et al. 2006), and transfer is, for good reasons, considered crucial for education. James Desse, in 1958, famously stated that "There is no more important topic in the whole psychology of learning than transfer of learning ... There is no point of education apart from transfer" (213). Bransford's group have also underscored the importance of transfer, as witnessed by the following quote "Educators hope that students will transfer learning from one problem to another within a course, from one year in school to another, between school and home, and from school to workplace" $(1999,51)$. But to quote Douglas Detterman: "If there is a general conclusion to be drawn from the [transfer] research it is that the lack of general transfer [i.e. non-specific transfer between structurally heteromorph situations] is pervasive and surprisingly consistent" $(1996,18)$. This might be because human learning is often fixated - to a place, a function, or a certain theme and/or subject (e.g. Sternberg and French 1996, 30). In any case, and in so far Detterman's conclusion is correct, it seems the argument from purpose is utopian more than realistic. To claim that that which 
does not happen happens more readily under active conditions than under conditions that are passive, might reasonably be described as wishful thinking.

An alternative to declaring the argument from purpose utopian might be to consider purposes for education other than transfer. There is a lucid discussion of the why of education in Elliot Eisner (1994). Under the heading "Six Curriculum Ideologies", Eisner considers religious orthodoxy, rational humanism, progressivism, critical theory reconceptualization and cognitive pluralism (56ff) as possible overarching purposes for education, as educational manifestations of Weltanchauungen (48). It would exceed the scope of this paper to consider Eisner's suggestions in detail. However, I recognize that the question of the purpose of education is a more fundamental question than the one I have been posing: which forms of learning are preferable? My question presupposes an answer to the question of why. But this, apart from a general commitment to general transfer, have not been provided. There is a distinction between normative and descriptive philosophy of education that might, at least partly, elucidate in this instance. What I attempt is a description of arguments pertaining to forms of learning, not a normative positioning. Still, I recognize that answers as to the how of education is dependent upon answers as to the why of it (cf. Frankena 1965, 6ff).

The argument from authority is the argument that since student active learning is the didactical concretization of student centred learning, and since student centred learning, at least in Europe (MSTI 2005, 38ff) and the OECD-countries (Dumont et al. 2010), represents the authority, the current state of the art as regards research on how students learn (and how teaching, consequently, should be executed), didactical situations should be arranged student actively. Marton and Säljö (1976; 1976b) is often credited with having initiated the field of research that investigates student approaches to learning (the SAL-tradition). The distinction between deep and surface approaches to learning, for example, currently being implemented in Norwegian comprehensive education (Meld. St. 28: 2015/16 - parliamentary white paper; cf. NOU 2014: 7-parliamentary green paper) derives from their work. David Kember (1997) is one of many researchers who have followed up on Marton and Säljö (cf. also Trigwell et al. 1999). He suggests distinguishing not only between students differing approaches to learning, but also between teachers differing approaches to teaching. Consequently, he identifies two different orientations among teachers, one being teacher-centred and content-oriented, whilst the other is student-centred and learning oriented. Under the latter orientation, student-activity is vital, almost per definition, because of its close connection to learning. Geven and Attard (2012) have argued that student centred learning is the key principle for the future of European education. They claim that under student centred conditions, learning "goes beyond simply imparting facts and knowledge to students" (167) and is characterized by "innovative methods ... active participants ... [and] fostering transferable skills" (155).

The problem with arguments from authority is, or can be, the authority in question. If the authority is a real authority (definition pending), there is no problem. This might explain why many consider The Bible an authoritative text. Why? Because it is the word of God, a real authority. If the authority is not a real authority, however, but rather an authority that is questionable (definition pending), basing one's reasoning, planning and practice upon it, of course becomes problematic. The challenge as regards authorities, consequently, is to distinguish between authorities that are real and authorities that are questionable. Descartes famously discussed this $(1968,95 \mathrm{ff})$. His argument is that if you base your reasoning upon 
an authority, you will need something to guarantee your authority. This would typically mean another authority. But if so, you face a regress, and so you might as well disregard authorities in the first place. If Descartes is right, this of course makes arguments from authority inherently problematic.

Relatedly, student centeredness is a highly, or perhaps even essentially, contested concept. As suggested above, different standards as regards the means to successful learning might have crystallized differently in different subjects during the centuries. According to the early Paul Hirst, there are irreducible forms of knowledge (1974). In so far this is correct, differences as to the best forms of learning seems more plausible than similarities in the same respect.

Above I have identified and discussed five arguments pertaining to student active forms of learning, and thereby suggested a characterization of the phenomenon. All the arguments are attributable to peer-reviewed research-literature, but as stated, I am responsible both for extrapolating the arguments and for naming them. I hope readers shall agree the attributions are not far-fetched. Note that the attempt above has been to investigate the arguments by way of internal, not external criteria. I have thus performed a kind of check of the arguments, most notably as regards their consistency, coherence, and consequences. I shall now proceed in the same way (check, not critique) with a discussion of the lecture as an allegedly passive form of learning. This I do since positioning active learning by that which it allegedly is not, seems a fruitful prospect.

\section{The Lecture-an Allegedly Passive Form of Learning}

The following section is organized in the same way as the previous - by way of arguments. The aim of the section is to characterize an allegedly passive form of learning, namely the lecture, and this is done by identifying and discussing some of the reasons given for and against it. Again, to get off the ground, it is useful to stipulate a definition of the key-term of the section. Again, following Freeman et al. (2014), "lecture" is defined as follows:

"Lecture" = def. "a lecture is a continuous exposition by a teacher [where] student activity ... [is] assumed to be limited to taking notes and/or asking occasional and unprompted questions of the instructor". (8414)

After having systematized parts of the literature pertaining to the lecture, I have extrapolated the following arguments from the material:

- The argument from engagement

- The modeling argument

- The inner speech argument

- The argument from the value of listening

- The pragmatic argument.

I will now present and discuss these arguments.

The argument from engagement is the argument that the lecture, far from being passive, traditional, instructional, and aimed only at transferring knowledge from a teacher to a student, 
is an active and engaging professional encounter. The argument has several feet. One foot is that the lecture is engaging for the students; another that it is engaging for the lecturer. If this is correct, there are also valuable feedback-loops to consider in this connection (a possible third foot). Small (2014) has argued that lectures are activating. He suggests that the lecture "invites discussion and dialogue" (3) and that it thereby affords both teachers and students the opportunity to interact with each other. Tokumitsu (2017), similarly, have argued that myriad things happen in a student when listening to someone perform an extended argument, i.e. a lecture, one of which is the activation, and hence the engagement, of the student. Note that "activation" here is to be understood along the lines of cognitive activation and as opposed to an activation that is behavioural (cf. the activity-argument above). As regards the lecture engaging the lecturer, there is a small passage in Rorty (1999) that sums this up nicely - about teachers "putting their individual, lovingly prepared specialities on display in the curricular cafeteria, without regard to any larger end" (125). As regards feedbackloops, it seems obvious that a shared interest in a common theme or subject is engaging for all involved parties. Following Small's suggestion and interpreting engagement in terms of "discussion and dialogue", it is further possible to suggest which form the feedback-loops might take: That they are dialectical and hence developmental.

One argument in particular stands opposed to the argument from engagement, however, and that is the argument from boredom. The argument from boredom is the argument that students are not really engaged in lecture halls, that they are instead — bored. Mann and Robinson, in reporting on a questionnaire-study, find that " $59 \%$ of students [in higher education; $\mathrm{N}=211$ ] consider their lectures boring half of the time and $30 \%$ find most or all of their lectures boring" $(2013,243)$. The authors define boredom as "having nothing to do that one likes" (243). Assuming these findings representative, they are of course a harsh verdict on teaching in higher education. Admittedly, there are reasons to believe in systematic differences as to students doing something "that one likes" in countries (or universities) where you pay for tuition as opposed to countries/institutions where higher education is free. Still, the findings in Mann and Robinson's study is a cause for concern.

Both the activity-argument and the argument from conceptual schemes would seem to presuppose that sustained, behaviourally passive concentration is difficult for the modern student. The argument from boredom, systematic national/institutional differences aside, might function as an explanation why this is so. I shall return to this point below when considering the question whether Google is making us stupid.

The modelling argument is the argument that lectures afford students the possibility to experience conduct exceptional to the extent of providing a template for what it means to belong to a Fach. The students can thus model their own professional conduct on these experiences, both their current and future one. Webster (2015) makes this argument when he claims that lecturers "model rigorous thinking and compelling ways of being a scholar for their students" (97). He further claims that there is a kind of thinking appropriate for higher education, and that you learn this by listening to an expert think aloud. French and Kennedy (2016), in assessing arguments in favour of the lecture, similarly suggest that the lecture provides the "opportunity for academics to present up-to-date research" — and the students the opportunity to "model [this] behaviour" (649).

The problem with the modelling argument is that occasionally, or perhaps even regularly or often, the conduct on display in lecture theatres is not much to model. Depending for 
example on the quality of the institution, not all lecturers present "lovingly prepared specialities" to their students. To the extent they do not, the modelling argument loses foundation. Imagine again Tracy the teacher, but now under two different descriptions. Description 1: Tracy enters the lecture theatre, reads verbatim from her Power Point presentation for two hours straight, whereupon she exits. It would seem this is not the most modelworthy conduct. On the other hand (description 2), assume that Tracy intersperses her reading with fresh talk, inviting questions from her audience or have them discuss with each other, or arrange a Padlet where the students might display their opinions. This of course comes closer to something to emulate.

The inner speech argument is the argument that the lecture is conducive to the production of inner speech, the dialogical/dialectical mental interplay so vital for learning. The argument derives from Vygotsky (1986) and his idea that understanding, the process of trying to make sense, is fundamental for human cognition. Understanding in Vygotskian terms might be described as follows: When we hear something, we inevitably try to adapt it to what we already know and/or understand. Further, we predict; that is, forecast or envision or project our understanding applied. This is the process of speaking internally: entertaining, to the best of our abilities, the diverse possibilities that open when we envision the application of something (1986, 217ff). On this background, Webster (2015) describes what happens in a lecture thus: "Rather than [students] passively listening to and 'accepting' a speech, there is continual activity going on inside people" (93; also refer back to the description of Sally under the activity-argument above). Quoting Vygotsky directly, Webster claims that this activity "is not a thing but a process, a continual movement back and forth from thought to world and from world to thought" (93; cf. Vygotsky 1986, 218). Fulford and Mahon (2018), similarly, have argued that students respond when listening to a lecture, that they are not passive: "The lecture must not be understood in terms of a unidirectional mode of transmission - a monological form of communication in which students are merely passive recipients" (1). The lecture, according to Fulford and Mahon, is rather to be conceived of as an address - as a reaching out.

Depending upon your epistemological position, you might consider there is a problem with the inner speech argument, namely that it is speculative. I distinguish "speculative" from "empirical", on the one hand, and "rational", on the other, and in this connection the terms denote ways to warrant statements. Assume the following question:- How do you know that inner speech is going on in your students when they listen to you lecture, that they are adapting new knowledge to their exiting knowledge base, that they project and envision applications, that they are not just-bored? The answer is that I do not. But I assume (speculate) that my students, at least some of them, perhaps even many, are entertaining internal conversations as I speak and that they are interested in, and internally investigating into, conditions of applicability as this pertains to what I am saying. By "assume", I mean that I find it strongly suggested that they do so, but that they do is neither empirically nor rationally warranted. Elsewhere, I have argued that student-learning is a black box (Opdal 2020). I submit that the best we as teachers can hope for in arranging didactical situations, is that our students in all probability learn, or at least that we do not preclude this possibility. Still, we cannot be certain learning is going to result. Both the argument from engagement and the modelling argument are relevant in this connection. To the extent that our teaching engages the students, and to the extent that our conduct is something to model, it would 
seem this is conducive to students entertaining inner speech. Still, that they do so is not something we know.

I shall below discuss a claim made by Wieman, that "[u]niversity teaching is in the early stages of a historic transition, changing from an individual folk art to a field with established expertise" $(2019,47)$. On this background, the speculative backing of the inner speech argument might seem flimsy. On the other hand, and as discussed above, neither the empirical argument nor the activity argument are absolutely compelling, in part due to conceptual issues. It might be, thus, that "folk art", even if used disparagingly by Wieman, is really another word for informed and/or rational — even if it stands opposed to "evidence-based".

The argument from the value of listening is the argument that students learn vital listening skills while attending lectures, and that these skills are not so easily attainable elsewhere. Tokumitsu (2017) makes this argument. She further makes the claim, not unreasonable, that listening is a skill much sought both outside and inside the academy. French and Kennedy (2016) also argues for the value of developing listening skills and that this readily happens in the lecture theatre. In addition, they argue that a corollary skill is developed in this connection, namely the skill of taking notes, and that there are few (if any) places where this skill is developed as effectively as in the lecture theatre (648). This seems plausible. Imagine Sally the student again. Dependent upon what Tracy the teacher says, and assuming this is engaging and conducive to Sally's inner speech, Sally will listen, assess, prioritize, and judge before or even as she makes her notes. It seems clear that this is a valuable skillset.

The argument from the value of listening appears strong. To be able to listen to, and hopefully to follow, extended arguments is indeed a valuable skill, as is the skill of taking notes and the (concurrently) developed abilities to prioritize and pass judgment. But assume now the following counter-argument:-At this day and age, the development of listeningand note-taking skills in the student body is not a vital task for the educational system, the teaching of it being indirect to boot. To listen is not what students need to learn. Why? Because if they wonder about something, they might just google it and get the information they need. Consequently, we should teach them how to assemble and assess on-line information, and this they learn best by hands-on, student active learning.

In 2008 Nicholas Carr famously posed the following question: Is Google making us stupid? He has, he says, "an uncomfortable sense that someone, or something, has been tinkering with [his] ... brain" (1). In the article, he describes how, since his reading habits have changed from reading books to mostly reading on-line, changed has also his way of thinking. He quotes Bruce Freidman, who reports how he has "almost totally lost the ability to read and absorb a longish article" (3), who says his thinking "has taken on a 'staccato' quality, reflecting how he quickly scans short passages of text from many sources" (3). In another piece, Carr argues that the "richness of our thoughts, our memories and even our personalities hinges on our ability to focus the mind and sustain concentration" (2010).

Carr's interest is how the internet (Google) affects our way of thinking, and so you might wonder what this has to do with the argument from the value of listening. The two instances tie together in the following way: How we do things, what kind of media or technology or tools we use, affect us in profound ways. Vygotsky is famous for having made this argument (1978, 39ff), as is Marshall McLuhan, as witnessed by the title of his most famous book: The medium is the message (2001). Precisely this, I take it, is the general message in Carr's pieces. What we get out of something, and per accumulation or aggregate: how we think, is 
at least partly dependent upon how things are presented to us. If this is correct, not teaching students to listen anymore might thus change them in ways we neither for-nor oversee. If, as argued above, the ability to prioritize and pass judgement is also developed when listening and/or writing in a lecture theatre, and if, as I suspect most would agree, these are names of valuable skills, the conclusion would seem to be that a precautionary principle is apposite in this connection.

The pragmatic argument is the argument that there are pragmatic, i.e. efficiency-reasons, for maintaining the lecture as a form of teaching in higher education.- - Given the massified university, there is little choice but to lecture on a large scale. Even if our students foremost request is formative assessment to a greater degree (as suggested in Damen et al. 2016, 20), this request is hard, if not impossible, to fulfil under current conditions and resources. Lecturing, on the other hand, is both effective and manageable, and so we should prioritize it. French and Kennedy (2016) argue to this effect when claiming that the lecture is an efficient method for teaching large groups of students (649). Mary Burgan (2006) also considers the pragmatic utility of lectures when she argues that many students in today's university find it difficult to raise their voices and ask questions, as they typically would have to in a seminar. In the lecture theatre, on the other hand, students might sit back and listen, not having to participate verbally.

In terms of the massified university, it seems the pragmatic argument is sound. Consider these figures: In my native Norway, the number of students in higher education has risen from approximately 10.000 in 1960 , to approximately 130.000 in 1990 , to approximately 300.000 in 2020 . The same trend is evident in the UK, where the corresponding numbers are approximately 250.000 (1960), 1.000 .000 (1990) and 1.900.000 (2020). This clearly indicates that questions relating to the allocation of resources must be high on the agenda for any university. In pragmatic terms, thus, there are good reasons to maintain lectures. On the other hand, there seems to be something inherently problematic with the idea of letting other considerations than professional opinion rule supreme in higher education. If the core idea of higher education is the pursuit of truth through criticism, admitting questions of resourceallocation to take pride of place, is arguably to admit them more than their fair share.

\section{Table of Arguments and Discussion}

Sections 2 and 3 above afford me the opportunity to develop a table of arguments pertaining to student active and (allegedly) student passive forms of learning. I now present the table before I discuss further some of the elements on it.

\begin{tabular}{|c|c|c|c|c|}
\hline \multicolumn{3}{|c|}{ Student active forms of learning } & \multicolumn{2}{|l|}{ The lecture } \\
\hline & $(\mathbf{A})$ & Contra (B) & Pro $(\mathbf{C})$ & Contra (D) \\
\hline 1 & $\begin{array}{l}\text { The empirical } \\
\text { argument }\end{array}$ & $\begin{array}{l}\text { Problems tied to notions of more/better } \\
\text { learning } \\
\text { Learning is organic } \\
\text { Opaque empirical backing }\end{array}$ & $\begin{array}{l}\text { The argument } \\
\text { from engagement }\end{array}$ & $\begin{array}{l}\text { The argument } \\
\text { from boredom }\end{array}$ \\
\hline 2 & $\begin{array}{l}\text { The activity } \\
\text { argument }\end{array}$ & $\begin{array}{l}\text { "Activity" is ambiguous between behavior } \\
\text { and cognition } \\
\text { Activity as a means to an end }\end{array}$ & $\begin{array}{l}\text { The modeling } \\
\text { argument }\end{array}$ & $\begin{array}{l}\text { Sub-optimal } \\
\text { teacher-conduct }\end{array}$ \\
\hline
\end{tabular}




\begin{tabular}{llll}
\hline Student active forms of learning & The lecture & \\
\hline $\begin{array}{l}\text { The argument } \\
\text { from concep- } \\
\text { tual schemes }\end{array}$ & $\begin{array}{l}\text { The constructivist teaching fallacy } \\
\text { ist theories of learning and constructivist } \\
\text { theories of teaching }\end{array}$ & $\begin{array}{l}\text { The inner speech } \\
\text { argument }\end{array}$ & $\begin{array}{l}\text { Speculative } \\
\text { backing }\end{array}$ \\
$4 \begin{array}{l}\text { The argument } \\
\text { from purpose }\end{array}$ & Problems tied to transfer of learning & $\begin{array}{l}\text { The argument } \\
\text { from the value of } \\
\text { listening }\end{array}$ & $\begin{array}{l}\text { Listening is not } \\
\text { a vital (21st cen- } \\
\text { tury) skill }\end{array}$ \\
$\begin{array}{l}\text { The argument } \\
\text { from authority }\end{array}$ & The inherent problem with authority & $\begin{array}{l}\text { The pragmatic } \\
\text { argument }\end{array}$ & $\begin{array}{l}\text { Professional opin- } \\
\text { ion, not pragma- } \\
\text { tism, should be the } \\
\text { last word in HE }\end{array}$ \\
\hline
\end{tabular}

Placing the arguments in a table provides a synoptic overview of the arguments and thus makes it easier to consider connections, relations, and differences between them. This might serve to put the arguments, and the propositions they are arguments for, into sharper focus. Note, however, that the arguments are of two different orders. The two sets of pro-arguments (A and C) pertain directly to the question posed in the introduction: Which forms of learning are preferable, active or allegedly passive forms - and why (cf. Sect. 1 above). A contains arguments in favor of student active forms of learning, whilst $\mathbf{C}$ contains arguments in favor of the lecture. However, some of the arguments under $\mathbf{A}$ are also arguments against the lecture, just as some of the arguments under $\mathbf{C}$ are arguments against student active forms of learning. Consequently, if these arguments are valid, they provide backing not just for student active forms of learning and the lecture, respectively, but also indicate why the "opposite" is non-preferable. The contra-arguments, on the other hand (B and D), pertain not to the question in the introduction, but to the different pro-arguments (B pertains to A and $\mathrm{D}$ to $\mathrm{C}$ ), even if indirectly there are connections between the two orders.

I shall now investigate into the key-term of the arguments, i.e. learning, in light of the preceding sections. Thereby I mean to suggest a further development of some of the arguments of the table. Assuming it well established that 'learning' is an inherently difficult concept, a main objective in this section is to detail/suggest why and how this is so. A question that arises is whether learning/good learning/better learning are suitable objects for research - and whether the notion of student active learning in higher education is strictly speaking coherent.

As discussed above, there are conceptual problems tied to several of the arguments grouped under A. The empirical argument is the argument that research shows that learning is better and/or more under active conditions than under passive, whilst the activity argument is the argument that this is due to a feature by our human nature. But what is learning? The arguments presuppose a precise construct/definition; yet this, as the contra-arguments (B1) make plain, is not provided. In the research-literature, definitions of "learning" range from "change in behavior" (Schunk 2009, 2), to change in capacity for behavior, for example change in "very general abilities and personal qualities — such as 'thinking critically' ... or 'being able to communicate effectively", (Ramsden 2003, 18). Further, it is argued that "we would regard change of behavior at best as only evidence of learning ... [neither] necessary [n]or sufficient" (Green 1969, 56) and that "[1] earning concerns conduct not behavior ... [a learner] wants to know what to think and what to believe and not merely what to do" (Oakeshott 2001, 36). Also, learning might be described in terms of both knowledge, skills and competence (MSTI 2005), in terms of competence, socialization and subjectification (e.g. 
Biesta 2016, 4; 64) and as both Bildung (e.g. von Oettingen 2018) and formation (e.g. Matlary 2011). This little enquête indicates the range of phenomena falling under the concept.

How is it supposed that a phenomenon this multifaceted might be an object for research? Or, more precisely, how is research based upon a construct that is undefined in the way indicated, supposed to form the basis for a precise didactical organization/prescription - student activity, which is supposed to result in good learning? Refer back to the claim in Deslauriers et al. (2011) discussed above, that "more than twice the learning" (862) occurred under active than under non-active conditions. What, precisely, is learning referring to here? Considering the distinction between documented and actual learning, we cannot be certain what the twice-ness refers to. Why? Because investigating into learning runs the risk of studying at one time behavior, at another (propensity for) change in behavior, at one time current knowledge base, at another current skill and performance level. And of course, all these facets are neither discrete nor independent of each other. And so, we do not know what we look at. Now, refer back to the consensus-definition of active learning quoted earlier. Active learning, according to this definition, is whatever engages students in the learning process. But what engages students, we now see, might be evidenced by both behavior and not, might be both in terms of conduct and not; it might show itself by not showing itself since passivity might be activity (cf. the discussion of the activity-argument above). The claim that empirical research into student-active learning establishes what works is on this background simply not credible, and hence the buzz about student activity as a one-size fits all because allegedly empirically validated, should be tempered.

In the above paragraph, the interest is products of learning as opposed to learning as process. However, also when it comes to the process of learning, there are considerable problems as to how to define it. Why? Because a process is that which is taking place, and so is unfinished until it is finished. This means learning is not only evidenced in different and mutually conflicting ways (knowledge and skills; behavior and not behavior) but is principally unstable since it in its process sense is ongoing.

Apart from "learning" denoting both process and product-dimensions, and to compound difficulties, what we describe as learning-situations are irreducibly characterized by a multiplicity of factors operative at the same time and hence is irreducibly characterized by feedback-loops. Assume the educational ur-situation: A teacher-Tracy, a student-Sally, and a something (a content) to be learnt - the mechanism of conceptual formation according to Vygotsky. Tracy introduces her theme, but Sally is unmotivated, or the introduction is too difficult, so Sally starts looking out the window with that look in her eyes. This in turn causes Tracy to question the quality of her introduction, and because this causes here to mumble a bit and not be her usual precise self, this causes Sally to think Vygotsky is just another dead white guy. But since Vygotsky is not, and since Sally later that night suspects as much, she figures she better give him another chance and fetches Mind in Society from her bag. And now she gets it, or at least some of it, whereupon she asks Tracy several intelligent questions the following day.

This description illustrates what a feedback-loop might mean in educational situations: the reciprocal influence of teacher, student, and content on each other. Assuming, as is reasonable, that Sally is usually taught together with someone, the reciprocal influence is soon leading to an exponential growth in feedback-loops. This, in turn, causes a complexity in the situation that is astounding. One way of describing the ensuing complexity is by introducing a notion of levels, thereby (analytically) keeping the different layers of feedback-loops 
apart (for example level 1: Tracy's introduction; level 2: Sally's response; level 3: Tracy's response to Sally's response; etc.). Yet, as it might be the case that not only the factors, but also the levels feed back on each other, this would not solve the difficulty, even if it helps describe it.

The raisonnement in the preceding paragraphs illustrates some of the problems tied to the idea that learning is something one might investigate into, establish what works in relation to, an prescribe a certain didactical organization of - student activity. But learning is not clearly defined, and since it is possibly not possible to do so in a way that is both apposite and interesting this idea is mistaken. Learning is both product, process and principally unstable - all at the same time. Talk of good learning, better learning, deep learning, etc. is thus hand-waving, or, at best, pointing.--There is clearly something interesting here, but we do not know how to approach it.

There is a concept of armchair-philosophy going around. The term is often used in an overbearing manner to denote idle thinking (as opposed to utilizing scientific method), thinking devoid of contact with the real world (since speculative or focusing, for example, on conceptual analysis). Wieman, quoted above, might serve as an example in this connection. He distinguishes between educational research in terms of a folk art, i.e. armchairbased and educational research as a field based on expertise, i.e. based on scientific method. His homepage states that he has "pioneered the use of experimental techniques to evaluate the effectiveness of various teaching strategies" (Wieman 2020).

To opponents of armchair-philosophy the following proposition is apposite. Admittedly, there are plenty of things that cannot be done in an armchair, for example investigating into the ways of people drinking in the morning (cf. Skjælaaen 2018), or the ways of people herding sheep in Marocco (cf. Geertz 1973) or reindeer in Northern Norway (cf. Nergård 2006). On the other hand, there are certainly things that one can investigate whilst thus positioned. What, exactly? Thinking that is non-empirical. Let me explain this by using again the notion of "warrant", by which I mean discursively represented evidence intended to justify claims and statements. As argued above, it is fruitful to distinguish between different types of warrants. First, there are empirical warrants. Example: "How do you know?"-I see it. Then there are rational warrants. Example: "How do you know?"-Because it (that which I know) follows, in a logically valid fashion, from something that is certain. Then there are speculative warrants. Example: "How do you know?"-Well, I do not know, exactly, but the indications are strong, and the implications are fruitful.

An armchair is not the best of places from which to warrant things empirically. Empirical warrants are generated by interaction with the world, and you do not interact with the world (outside you room) when placed in an armchair. To warrants things rationally and/or speculatively, on the other hand, it seems to me an armchair is a suitable place to be. Rational/ speculative thinking is namely not focused on what is the case in empirical terms. Rather, it might focus on the concepts you employ, either piecemeal or in terms of their internal consistency (e.g. Hirst 1974). Or it might focus on the values you presume when working empirically (e.g. Kvernbekk 2015), or on questions connected to methodological validity (e.g. Yin 2014). In any research endeavor there are questions not investigated empirically, but rather by semantical analysis, or by assessing willingness towards margins of error, or researcher bias, or questions whether descriptions should be thick or thin. These kinds of questions might be explored in an armchair. The notion of apposite is apposite in this connection. To empirically warrant statements is not always what is apposite. What is apposite 
depends upon the nature of the case, upon which questions you want answered. There are different kinds of warrants, of which the empirical is but one.

\section{Summing up and Inconclusive Conclusions}

In this section, I sum up some of the major points from the above pages. I also offer some perspectives on the preceding pages in terms of inconclusive conclusions.

Above I have identified and characterized student active forms of learning and the lecture, respectively. I have done this by way of a discussion and assessment of some of the arguments given for each of the two forms. Further, I have placed the arguments in a table. This I have done to represent the arguments perspicuously, in the interest of transparency and to ease navigation for potential readers. I have then investigated into semantical/terminological problems that pertain to the key-word of the arguments on the table, i.e. "learning", and suggested that it is undefined to the extent that we do not know which phenomena fall under it.

I asked several questions on the opening pages of the paper. One was the following. How do we best get our students to learn - by facilitating for student activity or by lecturing? As the above discussion show, this question is not an easy one to answer, since "best" on the background of the discussions of the different arguments, seems to be a matter of both, not one or the other. Student activity, in terms of behavioral activity, in terms of behavior as a means to an end, namely cognitive activity, has its place in an education that is best, just as lecturing, in terms of a teacher presenting an extended argument, thereby displaying conduct that is exemplary and that thus functions engaging for students, has it. To this extent, the question how we best get our students to learn, as indeed the title of the paper, is too reductive. Yet, reductionism is often a fruitful start - from which to introduce complexities.

Complexities I have introduced in Sect. 4, a result of which is two-fold. First, there are serious problems tied to conceptualizations of the core term of the investigation, i.e. learning. On the empirical argument it would seem learning is a thing, measurable and subject to quantification in terms of more and less. However, as my above discussions indicate, this is mistaken. It is more apposite (even if a lot more difficult) to conceptualize learning as organic, i.e. as subject to perceived conditions of applicability, as characterized by feedback-loops and hence multilevel. Human learning is not primarily incremental, but characterized by daring and wonder, jumps over cliffs, push and pull — of sudden revolutions. Or, to put it better, it is also thus characterized. The argument is not that human learning is never incremental, it often is. The argument is that it is also more than this, which makes quantification of it inherently problematic. This is the second thing that is noteworthy considering the above. Because of the nature of learning, empirical investigations into it are intrinsically troublesome. Why? Because as far as learning is concerned, we do neither know what to look for, nor when to look for it, nor how to measure what we look for should we find it. Documented learning is the best we get, and it is not always bad-but to represent learning, neither is it good enough.

An important result of the above discussions is that it makes scarce sense to describe the lecture as passive. As both the argument from the value of listening and the inner speech argument make plain, there are different ways to be active. Cognitive activity, according to the inner speech argument, is the constant entertainment (testing) of emergent ideas, under- 
standings, analyses and hypotheses. The value of listening, according to the argument by the same name, and the concurrent value of taking notes, at least partly consist in choosing, i.e. discriminating or judging between what to pay attention to and what not. Judging and paying attention are names of activities. Mayer's distinction between behavioral and cognitive activity brings this point out nicely.

I also posed another question in the introduction, namely the following. Are we, as teachers in higher education, knowledgeable to the extent of being positioned to tell our students what is the case, or should we rather look upon ourselves as guides to, or facilitators of students' learning? Considering the modeling-argument and the argument from engagement, I might posit that some of us are thus positioned and some of us are not. To the extent that our conduct is model-worthy, to the extent that we are able to engage, it would seem our students admit us the position of expert, or at least that boredom is not prevalent in such cases. Then it seems that telling students what is the case, is compatible with facilitating their learning.

Funding Open access funding provided by UiT The Arctic University of Norway (incl University Hospital of North Norway).

Open Access This article is licensed under a Creative Commons Attribution 4.0 International License, which permits use, sharing, adaptation, distribution and reproduction in any medium or format, as long as you give appropriate credit to the original author(s) and the source, provide a link to the Creative Commons licence, and indicate if changes were made. The images or other third party material in this article are included in the article's Creative Commons licence, unless indicated otherwise in a credit line to the material. If material is not included in the article's Creative Commons licence and your intended use is not permitted by statutory regulation or exceeds the permitted use, you will need to obtain permission directly from the copyright holder. To view a copy of this licence, visit http://creativecommons.org/licenses/by/4.0/.

\section{References}

Barnett, M., and S. J. Ceci. 2002. When and where do we apply what we learn? A taxonomy for far transfer. Psychological Bulletin 128(4): 612-637. https://doi.org/10.1037//0033-2909.128.4.612.

Biesta, G. 2016. The beautiful risk of education (first published 2013 by Paradigm Publishers). London \& New York: Routledge.

Biggs, J., and C. Tang. 2011. Teaching for quality learning at university, 4th ed. Maidenhead: McGrawHill.

Bransford, J. D., A. L. Brown, R. R. Cocking, M. S. Donovan, and J. W. Pellegrino, eds. 1999. How people learn: Brain, mind, experience, and school. Washington, DC: National Academy Press.

Burgan, M. 2006. In defense of lecturing. Change: The magazine of higher learning 38(6): 30-34. https:// doi.org/10.3200/CHNG.38.6.30-34.

Carr, N. 2008. Is google making us stupid? In The Atlantic, July/August 2008. On-line here: https://www. theatlantic.com/magazine/archive/2008/07/is-google-making-us-stupid/306868/.

Carr, N. 2010. Does the internet make you dumber? In The Wall Street Journal, June 5th 2010.

Clark, R. E., P. A. Kirschner, and J. Sweller. 2012. Putting students on the path to learning: The case for fully guided instruction. American Educator 36(1): 6-11.

Damen, M.-L-, Keller. L. Hamberg, S. \& P. Bakken. 2016. Studiebarometer 2015: hovedtendenser. Rapport 1-2016. Oslo: NOKUT. On-line here: https:/www.nokut.no/globalassets/studiebarometeret/2016/studiebarometeret_2015_hovedtendenser_1-2016.pdf [available in Norwegian only].

Deslauriers, L., E. Schelew, and C. Wieman. 2011. Improved learning in a large-enrollment physics class. Science 332: 862-864. https://doi.org/10.1126/science.1201783.

Descartes, R. 1968. Discourse on Method and the Meditations (translated and with an introduction by F.E. Sutcliffe). London: Penguin Books.

Desse, J. 1958. Transfer of Training: The Psychology of Learning. New York: McGraw-Hill. 
Detterman, D. 1996. The case for the prosecution: Transfer as epiphenomenon. In Transfer on Trial: Intelligence, Cognition, and Instruction, eds. D. Detterman \& R. Sternberg, 1-24. Norwood, NJ: Ablex Publishing Company.

Detterman, D., and R. Sternberg. 1996. Transfer on Trial: Intelligence, Cognition, and Instruction. Norwood, NJ: Ablex Publishing Company.

Dumont, H., D. Istance, and F. Benavides. 2010. eds. The Nature of Learning. Using Research to Inspire Practice. OECD: Centre for Educational Research and Innovation.

Eisner, E. 1994. The Educational Imagination. On the Design and Evaluation of School Programs, 3rd ed. Upper Saddle River, NJ: Prentice Hall.

Frankena, W. 1965. Three Historical Philosophies of Education. Scott, Foresman \& Company: Glenview, Ill.

Freeman, S., S. L. Eddy, M. McDonough, M. K. Smith, N. Okoroafor, H. Jordt, and M. P. Wenderoth. 2014. Active learning increases student performance in science, engineering and mathematics. Proceedings of the national academy of sciences of the United States of America 111(23): 8410-8415. https://doi. org/10.1073/pnas.1319030111.

French, S., and G. Kennedy. 2016. Reassessing the value of university lectures. Teaching in Higher Education 22(6): 639-654. https://doi.org/10.1080/13562517.2016.1273213.

Fulford, A., and Á Mahon. 2018. A philosophical defence of the traditional lecture. In Times higher education, April 28th 2018. On-line here: https://www.timeshighereducation.com/blog/ philosophical-defence-traditional-lecture.

Forskrift om tilsyn med utdanningskvaliteten i høyere utdanning (studietilsynsforskriften). 2017. On-line here: https://lovdata.no/dokument/SF/forskrift/2017-02-07-137.

Gauci, S. A., A. M. Dantas, D. A. Williams, and R. E. Kemm. 2009. Promoting student-centered active learning in lectures with a personal response system. Advances in Physiology Education 33(1): 60-71. https://doi.org/10.1152/advan.00109.2007.

Geertz, C. 1973. The Interpretation of Cultures: Selected Essays. New York: Basic Books.

Geven, K., and A. Attard. 2012. Time for student-centred learning. European Higher Education at the crossroads: Between the Bologna process and national reforms, 153-172. Dodrecht: Springer. https://doi. org/10.1007/978-94-007-3937-6_9.

Green, T. F. 1969. A topology of the teaching concept. In Concepts of Teaching: Philosophical essays, eds. C. J. B. MacMillan, and T. W. Nelson, 28-62. Chicago, IL: Rand McNally.

Haskell, R. 2001. Transfer of Learning: Cognition, Instruction and Reasoning. San Diego: Academic Press.

Hirst, P. 1974. Liberal Education and the Nature of Knowledge. In Knowledge and the Curriculum. A Collection of Philosophical Papers, 30-53. London: Routledge \& Kegan Paul.

Illeris, K. 2012. Laering. Oslo: Gyldendal akademisk.

Kember, D. 1997. A reconceptualisation of the research into university academics' conceptions of teaching. Learning and Instruction 7(3): 255-275. https://doi.org/10.1016/S0959-4752(96)00028-X.

Kvernbekk, T. 2015. Evidence-based Practice in Education. Functions of Evidence and Causal Presuppositions. Routledge: London \& New York.

Leberman, S., L. McDonald, and S. Doyle. 2006. The transfer of Learning: Participants Perspectives of Adult Education and Training. Hampshire, UK: Gower Publishing Limited.

Mann, S., and A. Robinson. 2013. Boredom in the lecture theatre. British Educational Research Journal 35(2): 243-258. https://doi.org/10.1080/01411920802042911.

Marton, F., and R. Säljö. 1976. On qualitative differences in learning I - outcome and process. British Journal of Educational Psychology 46: 4-11.

Marton, F., and R. Säljö. 1976b. On qualitative differences in learning II - outcome as a function of the learner's conception of the task. British Journal of Educational Psychology 46: 115-127.

Matlary, J. H. 2011. Arven fra Athen, Jerusalem og Roma: Et forsvar for det klassiske dannelsesprogram. In Dannelse: Tenkning, modning, refleksjon, eds. B. Hagtvet, and G. Ognjenovic, 141-155. Oslo: Dreyers forlag. [available in Norwegian only].

Mayer, R. 2004. Should there be a three-strikes rule against pure discovery learning? The case for fully guided methods of instruction. American Psychologist 59(1): 14-19.https://doi.org/10.1037/0003-066X.59.1.14.

Mayer, R. 2009. Constructivism as a theory of learning versus constructivism as a prescription for instruction. In Constructivist Instruction: Success or Failure? eds. S. Tobias, and T. M. Duffy, 184-200. New York \& London: Routledge.

McLuhan., M. 2001. The Medium is the Message. Berkeley, CA: Ginko Press.

Meld.St. 28 (2015-2016): Fag-Fordypning-Forståelse: En fornyelse av kunnskapsløftet. Online here: https:/www.regjeringen.no/contentassets/e8e1f41732ca4a64b003fca213ae663b/no/pdfs/ stm201520160028000dddpdfs.pdf.

Ministry of Science, Technology and Innovation. 2005. A framework for qualifications of the European higher education Area, Bologna Working Group on Qualifications Frameworks. Technology and Innovation: København/Copenhagen: Ministry of Science. 
Nergård, J. I. 2006. Den levende erfaring. En studie i samisk kunnskapstradisjon. Cappelen akadmisk forlag: Oslo [available in Norwegian only].

NOU. 2014. 7 (2014): Elevens læring I fremtidens skole. Kunnskapsdepartementet: Oslo. On-line her: https://www.regjeringen.no/contentassets/e22a715fa374474581a8c58288edc161/no/pdfs/ nou201420140007000dddpdfs.pdf.

Oakeshott, M. 2001. Learning and teaching. In The Voice of Liberal Learning, 35-61. Indianapolis: Liberty Fund.

Opdal, P.A. 2018. Fra undervisning til læring? Vitenskapelig ansatte reflekterer over egen undervisningshverdag. Nordic Studies in Education 38(3): 252-270. https://doi.org/10.18261/ issn.1891-5949-2018-03-05.

Opdal, P.A. 2020. Inside the black box: On the concpts 'teaching' and 'learning' and the connections between them. Scandinavian Journal of Educational Research 64(3): 457-470. https://doi.org/10.1080/003138 31.2019.1577752.

Piaget, J. 1967. The Psychology of Intelligence. London: Routledge \& Keagan Paul Ltd.

Ramsden, P. 2003. Learning to Teach in Higher Education, 2nd ed. Abingdon, OX: RoutledgeFalmer.

Richardson, V. 2003. Constructivist Pedagogy. Teachers College Record 105(9): 1623-1640. https://doi. org/10.1046/j.1467-9620.2003.00303.x.

Rorty, R. 1999. Education as socialization and as individualization. In Philosophy and Social Hope, 114-126. London: Penguin Books.

Schunk, D. 2009. Learning Theories: An Educational Perspective, 5th ed. Upper Saddle River, NJ: Pearson Prentice Hall.

Skjælaaen, Ø. 2018. Meningen med rus. Oslo: Res Publica [available in Norwegian only].

Small, A. 2014. In defence of the lecture. In The Chronicle of Higher Education, May 27th 2014. On-line here: https://www.chronicle.com/article/In-Defense-of-the-Lecture/146797.

Smart, K. L., and N. Csapo. 2007. Learning by doing: Engaging students through learner-centered activities. Business and Professional Communication Quarterly 70(4): 451-457. https://doi.org/10.1177/108056 99070700040302.

Sternberg, R., and P. French. 1996. Mechanisms of transfer. In Transfer on Trial: Intelligence, Cognition, and Instruction, eds. D. Detterman \& R. Sternberg, 25-38. Norwood: Ablex.

Tokumitsu, M. 2017. In defense of the lecture. In Jacobin, February 26th 2017. On-line here: https://jacobinmag.com/search?query=tokumitsu.

Trigwell, K., M. Prosser, and F. Waterhouse. 1999. Relations between teachers' approaches to teaching and students' approaches to learning. Higher Education 37: 57-70. https://doi.org/10.1023/A:1003548313194.

Tyler, R. 1949. Basic Principles of Curriculum and Instruction. Chicago: The University of Chicago Press.

Yin, R. 2014. Case Study Research: Design and Methods, 5th ed. Los Angeles: Sage Publications Inc.

Yureich, R. F., and L. C. Kanner. 2015. Examining the Effectiveness of team-based learning (TBL) in different classroom settings. Journal of Geoscience Education 63 (2): 147-156. https://doi.org/10.5408/13-109.1.

Von Oettingen, A. 2018. Undervisning er dannelse. Aarhus: Aarhus University Press [available in Danish only].

Vygotsky, L. S. 1978. Mind in Society. The Development of Higher Psychological Processes. Cambridge MA \& London: Harvard University Press.

Vygotsky, L. S. 1986. Thought and Language (revised and expanded edition). Cambridge MA \& London: MIT Press.

Webster, R. S. 2015. In defence of the lecture. Australian Journal of Teacher Education 40(10): 88-105. https://doi.org/10.14221/ajte.2015v40n10.6.

Wieman, C. 2014. Large-scale comparison of science teaching methods sends a clear message. Proceedings of the National Academy of Sciences of the United States of America 111(23): 8319-8320. https://doi. org/10.1073/pnas.1407304111.

Wieman, C. 2019. Expertise in university teaching \& the implications for teaching effectiveness, evaluation \& training. Doedalus, fall 2019, 47-78. https://doi.org/10.1162/daed a 01760 .

Wieman, C. 2020. Homepage at Stanford Graduate School of Education. On-line here: https://ed.stanford. edu/faculty/cwieman.

Publisher's Note Springer Nature remains neutral with regard to jurisdictional claims in published maps and institutional affiliations. 